\title{
RANCANG BANGUN SISTEM INFORMASI \\ LAPORAN ANGGARAN PENDAPATAN DAN BELANJA PADA BKM TAMBAKREJO
}

\author{
Siti Sufaidah', Moh. Farih 'Alil Himam²) \\ Fakultas Teknologi Informasi Universitas KH.A. Wahab Hasbullah \\ ${ }^{1)}$ s.sufaidah@gmail.om, ${ }^{2)}$ e-mail : mfarihalilhimam@gmail.com
}

\begin{abstract}
ABSTRAK
Pada setiap kegiatan Organisasi pasti membutuhkan sumber dana baik dari luar maupun dari dalam untuk mempermudah proses pelaksanaannya, dan pada setiap kegiatan yang terealisasi mempunyai laporan yang berbeda-beda sesuai dengan sumber dana yang disepakati, dan laporan tersebut dituntut untuk setransparan mungkin agar tidak ada perbedaan dalam pemikiran. Dengan demikian dibuatlah Siistem Informasi untuk mempermudah membuat laporan secara tepat dan terperinci disetiap alokasi dana yang dilaporkan.

Kata kunci : Laporan, Sistem Informasi, Visual Foxpro

\section{ABSTRACT}

At any activities of the Organization in definite need of funding sources both from outside and from inside to facilitate the implementation process, and in any activity that is realized to have a report varies according to the source of the funds agreed upon, and the report is required to be as transparent as possible so that there is no difference in thought. Thus made Siistem information to easily create precise and detailed reports on each allocation of funds were reported.
\end{abstract}

Keywords : Reports, Information Systems, Visual Foxpro 


\section{Pendahuluan}

Program Penanggulangan Kemiskinan di Perkotaan (P2KP) dilaksanakan sejak tahun 1999 sebagai salah satu upaya pemerintah untuk membangun kemandirian masyarakat dan pemerintah daerah dalam menanggulangi kemiskinan secara berkelanjutan, Program ini sangatlah strategis karena menyiapkan landasan kemandirian masyarakat berupa Organisasi Badan Keswadayaan Masyarakat (BKM). Pada BKM ini diharapkan mampu menjadi wadah perjuangan kaum miskin dalam menyuarakan aspirasi dan kebutuhan mereka, sekaligus mampu mengelola dana dari pemerintah untuk penanggulangan kemiskinan.

Ada 4 Pengolahan dana Penanggulangan kemiskinan, diantaranya :

1. BOP (Biaya Oprasional)

2. UPS (Unit Pengelola Sosial)

3. UPL (Unit Pengelola Lingkungan)

4. UPK (Unit Pengelola Keuangan)

Dari keempat pengolahan dana tersebut BKM diharuskan mampu menyusun laporan penggunaan dana secara transparan, rinci dan jelas untuk mengantisipasi adanya kecurangan / penggelapan dana yang sudah di berikan oleh pemerintah baik dari pemerintah daerah maupun pusat.

\section{Kajian Teori}

\subsection{Sistem Informasi}

Sistem adalah sekumpulan komponen yang saling terkait yang bekerjasama untuk mencapai tujuan tertentu. Dapat dikatakan bahwa jika terdapat suatu elemen yang tidak membantu dalam upaya mencapai tujuan maka elemen tersebut bukan merupakan bagian dari sistem.

Informasi adalah data yang telah diolah menjadi bentuk yang lebih berarti bagi penerimanya dan bermanfaat.

Maka sistem informasi dapat didefinisikan sebagai suatu susunan dari orang, data, proses dan teknologi informasi yang saling berhubungan untuk mengumpulkan, memproses, menyimpan dan menyediakan keluaran informasi yang diperlukan untuk mendukung suatu organisasi.

\section{Analisis dan Perancangan Sistem}

\subsection{Pengertian BKM}

BKM adalah dewan pimpinan kolektif masyarakat warga penduduk kelurahan, dan sebagai lembaga BKM dapat bertindak sebagai representasi masyarakat warga penduduk kelurahan.kedudukan BKM di masyarakat kelurahan/desa adalah sebagai lembaga pimpinan masyarakat warga penduduk kelurahan dan merupakan lembaga pengendali kegiatan penanggulangan kemiskinan di kelurahan yang bersangkutan, yang posisinya di luar institusi pemerintah, militer, agama, pekerjaan dan keluarga

BKM dibangun sebagai pimpinan kolektif diperlukan dikarnakan :

1. Ketika masyarakat melihat kemiskinan sebagai persoalan bersama yang harus ditangulangi bersama sehingga diperlukan lembaga pimpinan yang mampu mengendalikan gerakan bersama tersebut,

2. Untuk dapat memimpin gerakan penangulangan kemiskinan dari, oleh dan untuk masyarakat sebagai upaya bersama.

\subsection{Analisis Sistem}

Pada tahap ini kegiatan yang dilakukan adalah menganalisis sistem yang berjalan untuk kemudian menyimpulkan permasalahan yang terjadi khususnya dalam penyampaian informasi dana masuk dan keluar yang dilakukan. Tahap ini merupakan dasar bagi tahapan perencanaan sistem yang dapat memaksimalkan pengolahan data dan penyampaian informasi. 


\subsubsection{Gambaran Sistem Yang Berjalan}

Berdasarkan penelitian diketahui bahwasanya dalam perancangan sistem pelaporan di BKM Tambak Rejo desa Tambakrejo Kecamatan Jombang ini menggunakan pencatatan menggunakan Excel, penggunaan komputerisasi masih bersifat data pada komputer dan berupa cetak.

\subsubsection{Gambaran Sistem Yang Diusulkan}

Berdasarkan uraian sistem yang sedang berjalan,maka penulis mengusullakn pengembangan Sistem Informasi Laporan Keuangan BKM Tambak Rejo. Pembangunan aplikasi ini ditujukan untuk membantu Sekretaris BKM dalam mengolah data dan pelaporan dana secara transparent.

Sistem informasi yang diusulkan adalah:

a.Diusulkan pengembangan sistem informasi laporan keuangan bebasis dekstop sehingga dapat digunakan dengan mudah.

b. Proses perhitungan penggabungan antar dana secara otomatis.

c.Keunggulan sistem yang diusulkan

d. Sistem ini meminimalkan keterlambatan laporan dan tingkat kesalahan pada pelaporan.

e.Sistem yang diusulkan dapat diperbarui secara berkala.

f. Mempermudah dalam penggabungan dana serta pengelompokan dana.

\subsection{Perancangan Sistem}

Dalam tahap desain sistem ini, menggambarkan aktifitas bagian informasi Pelaporan Keuangan BKM Tambak Rejo berupa alur informasi data dari sistem yang baru (context diagram), kemudian diuraikan menjadi beberapa proses yang ada dalam sistem. Berikut ini bentuk DFD level konteks yang akan dibangun :

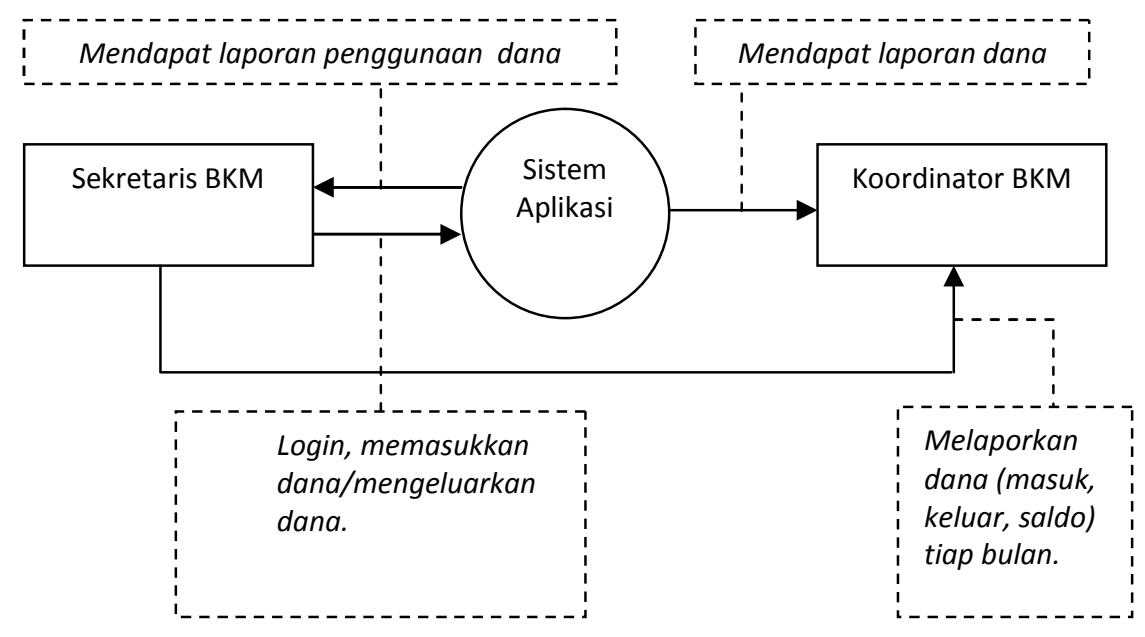

Gambar 1. DFD level konteks

Adapun untuk alur proses dari sistem yang akan dibangun dalam bentuk flowchart sebagai berikut : 


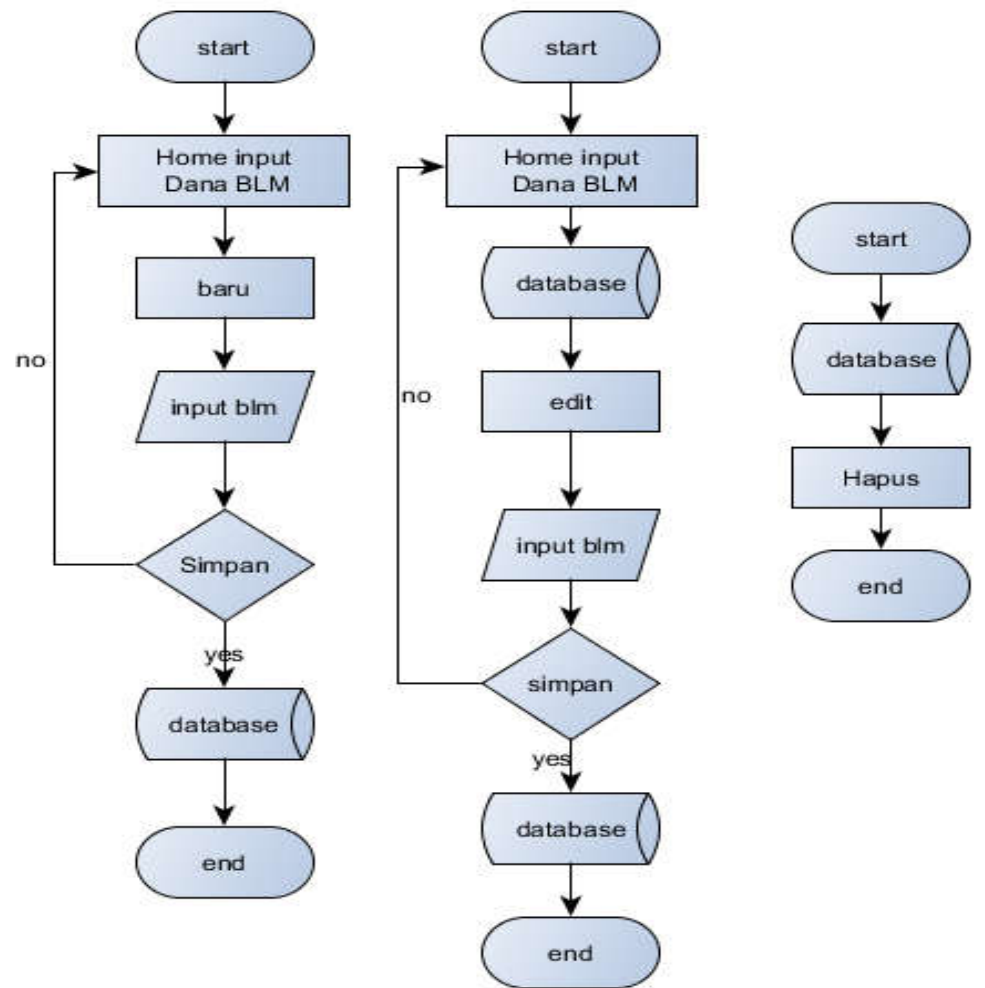

Gambar 2. Flowchart Dana BLM

\subsubsection{Perancangan Interface / Antarmuka}

1. Form Login

Fungsi dari form login digunakan untuk pengamanan sistem dari pengguna yang tidak terdaftar. Dengan form login ini penggunaan sistem dapat diawasi.

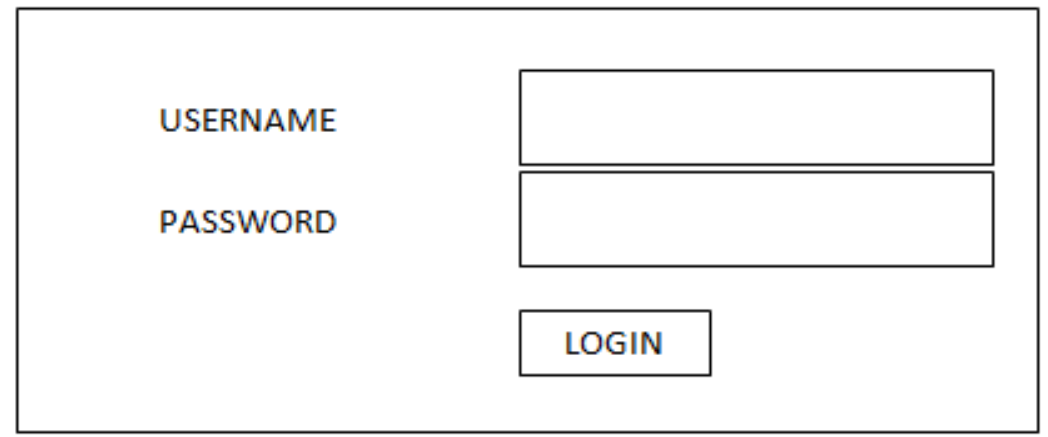

Gambar 3. Perancangan Form Login

2. Form Utama

Fungsi dari form utama digunakan sebagai media penghubung untuk menggunakan menu - menu yang terdapat dalam sistem. Form utama dapat diakses jika pengguna sudah memasukkan username dan password dengan benar pada form login. 


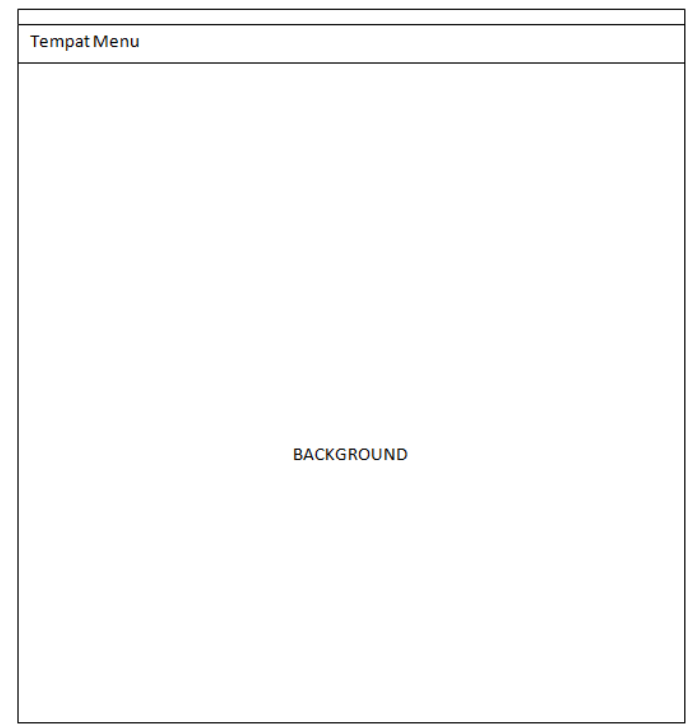

Gambar 4. Perancangan Form Utama

3. Form Neraca

Adapun desain form neraca ini, digunakan untuk sebagai interface input data neraca.

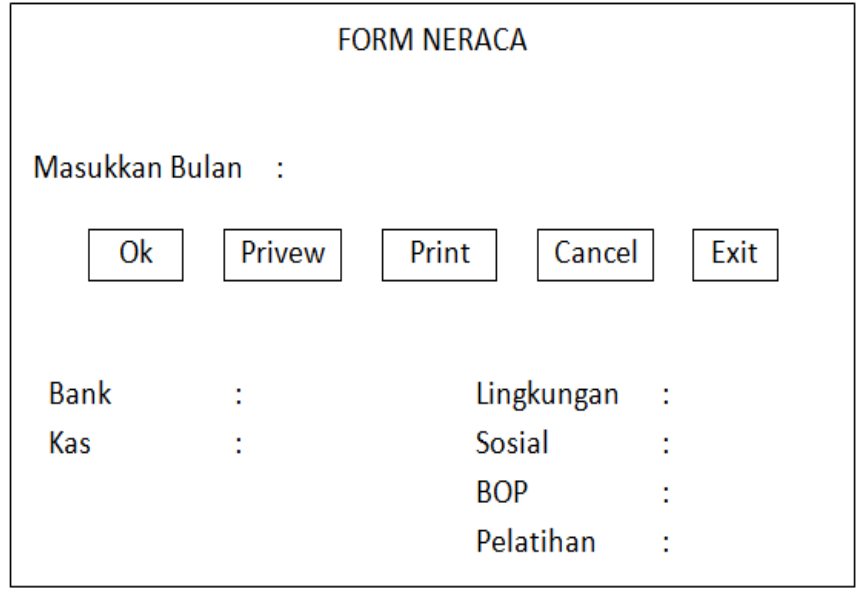

Gambar 5. Form Neraca

4. Form Arus Kas

Form ini digunakan sebagai interface untuk pengolahan arus kas pada sistem, adapun desain form arus kas sebagai berikut : 


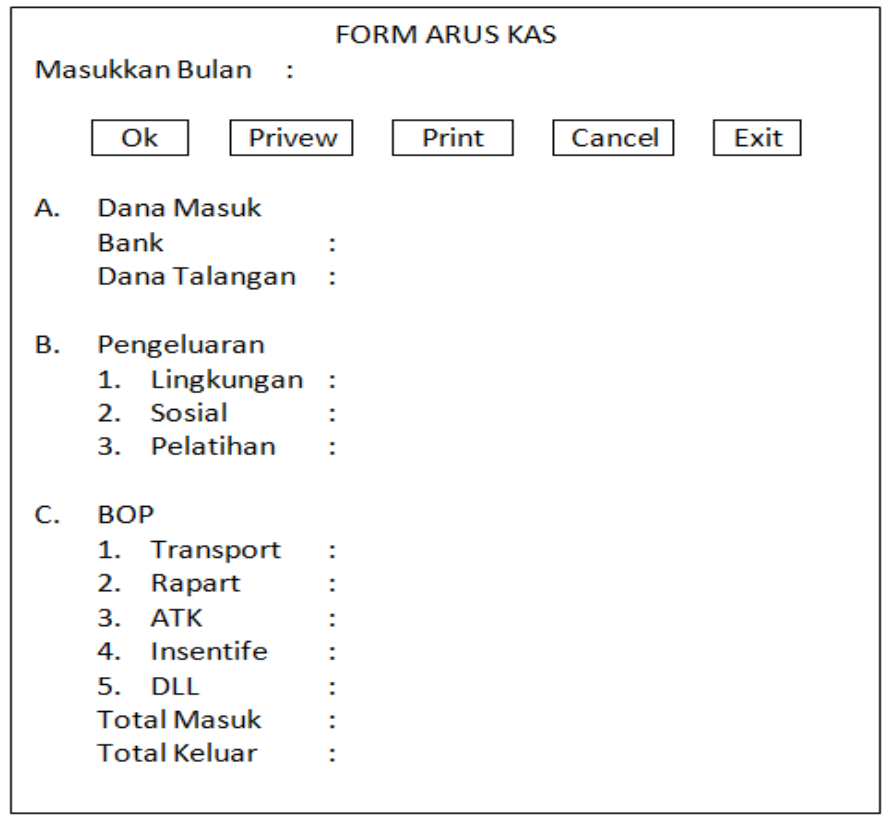

\section{Gambar 6 Form Arus Kas}

\section{Pembahasan}

Dalam sub ini akan membahas tentang pembahasan implementasi dari Sistem Aplikasi Laporan Keuangan BKM Tambk Rejo, seperti yang sudah di jelaskan pada sub bab sebelumnya tentang implementasi sistem. Berikut adalah beberapa implementasi system yang sudah dilakukan.

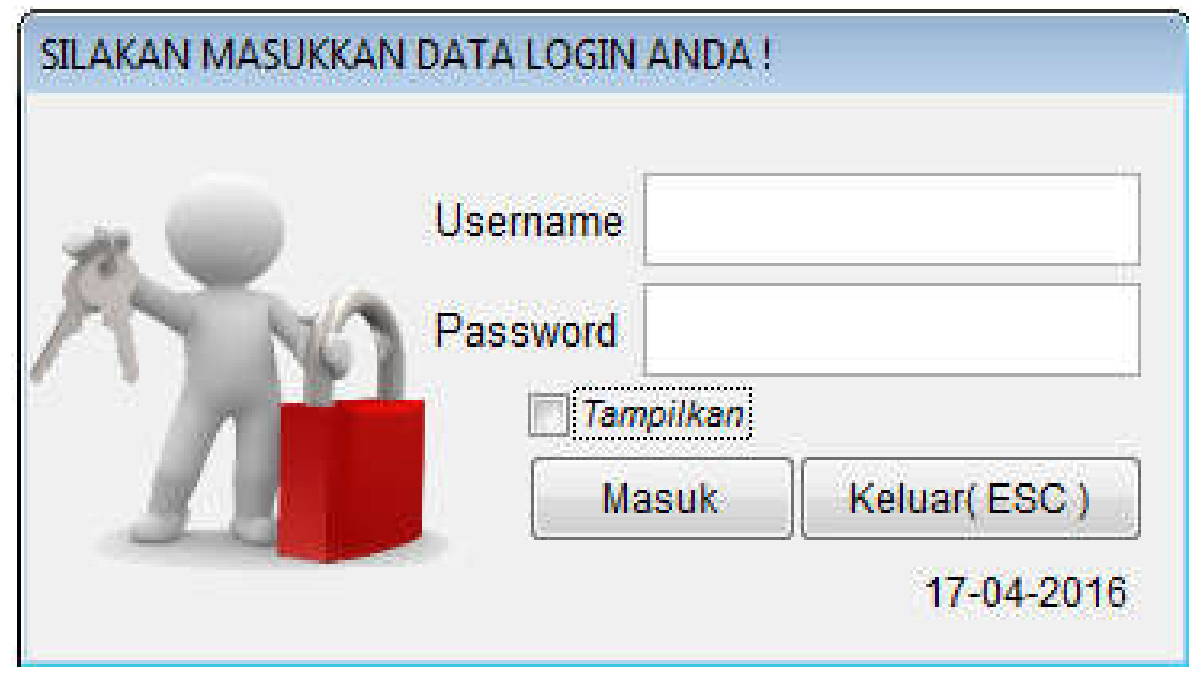

Gambar 7. Tampilan Form Login

Form login ini digunakan sebagai media pengaman sistem dari pengguna yang tidak berhak menggunakan sistem, pengguna dapat menggunakan sistem jika memiliki username dan password.

Adapun form utama dari sistem sebagaimana pada gambar 8 akan muncul jika pengguna sudah memasukkan username dan password dengan benar 


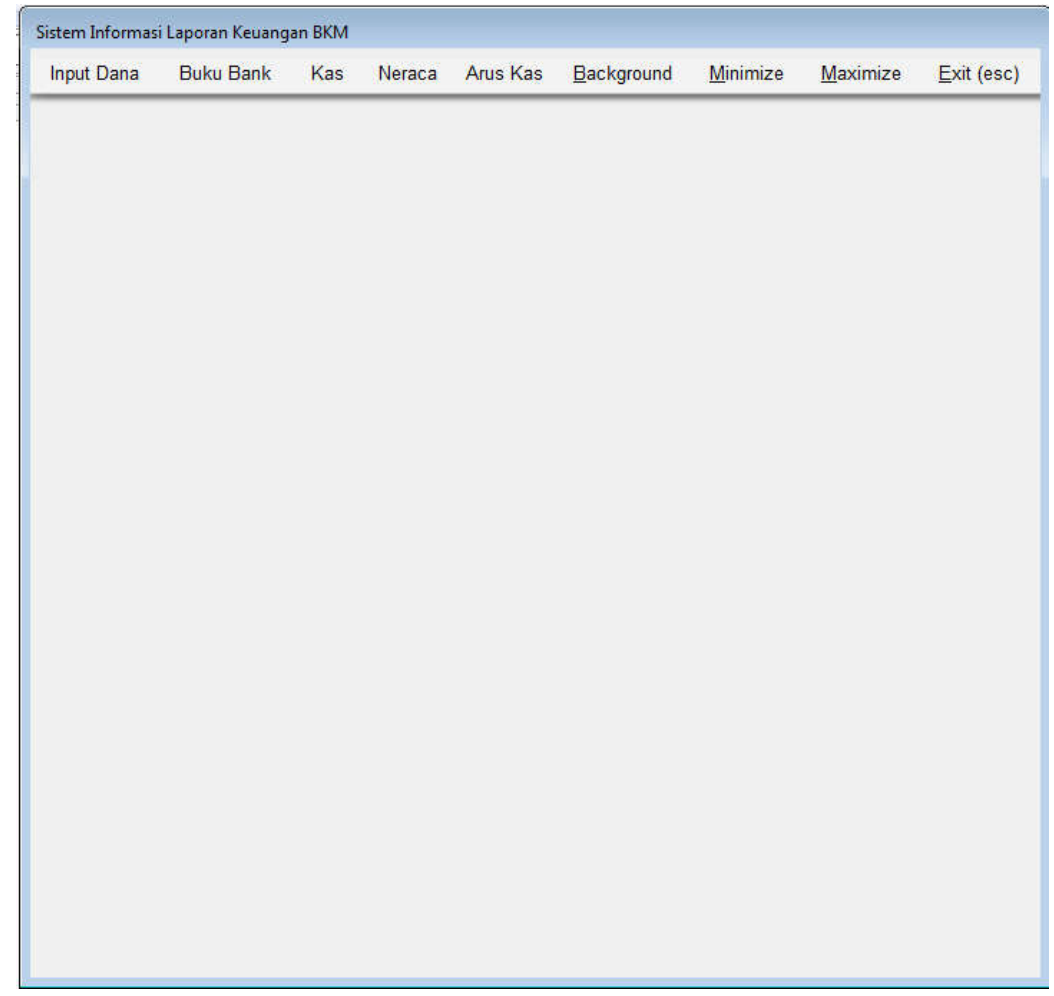

Gambar 8. Tampilan Form Utama

Sedangkan form dana BLM digunakan untuk mencata nilai alokasi pada bagian - bagian yang sudah didefinisikan. Adapun tampilan dari interface sebagaimana pada gambar 9. Berikut ini :

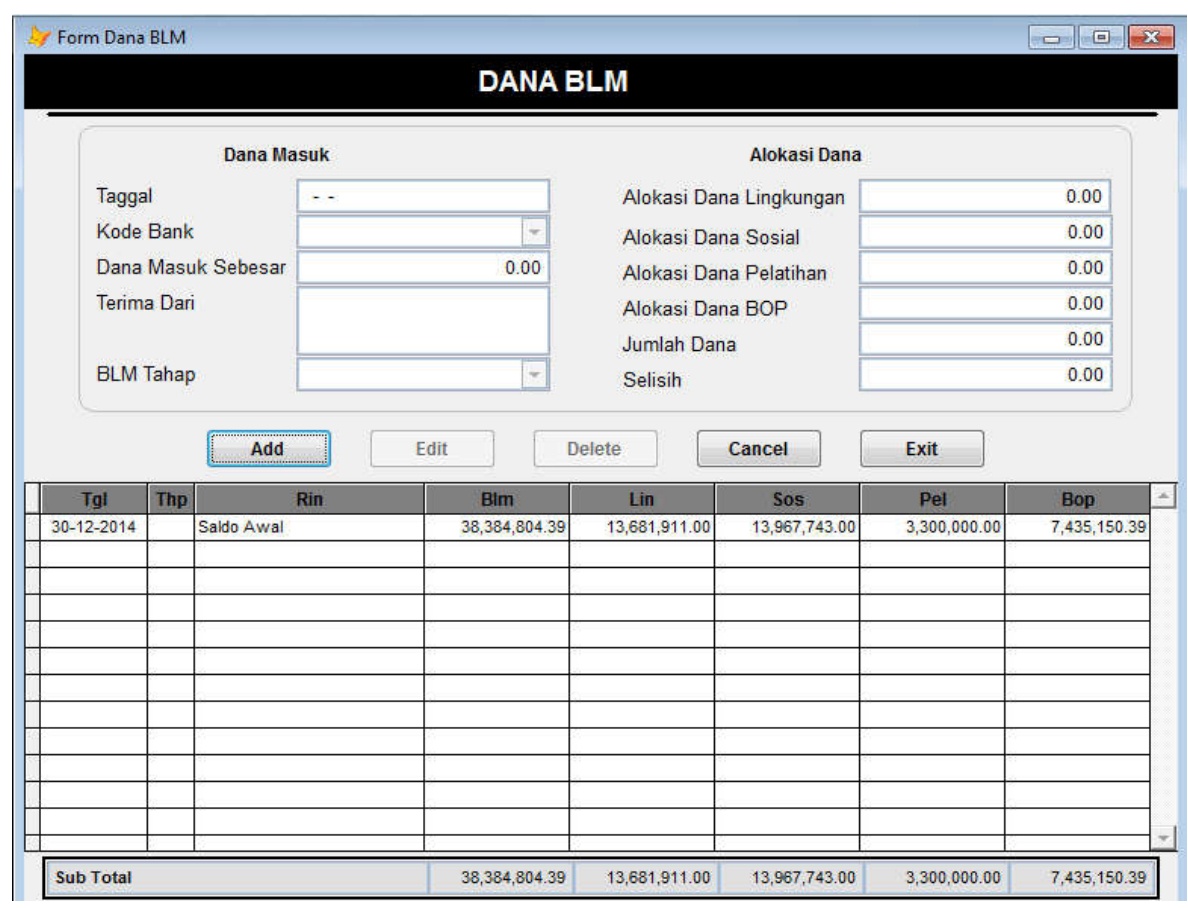

Gambar 9. Tampilan Form Input Dana BLM 
Untuk memudahkan komunikasi terkait dengan sirkulasi yang ada pada buku bank, maka dibuatlah form buku bank sebagai berikut :

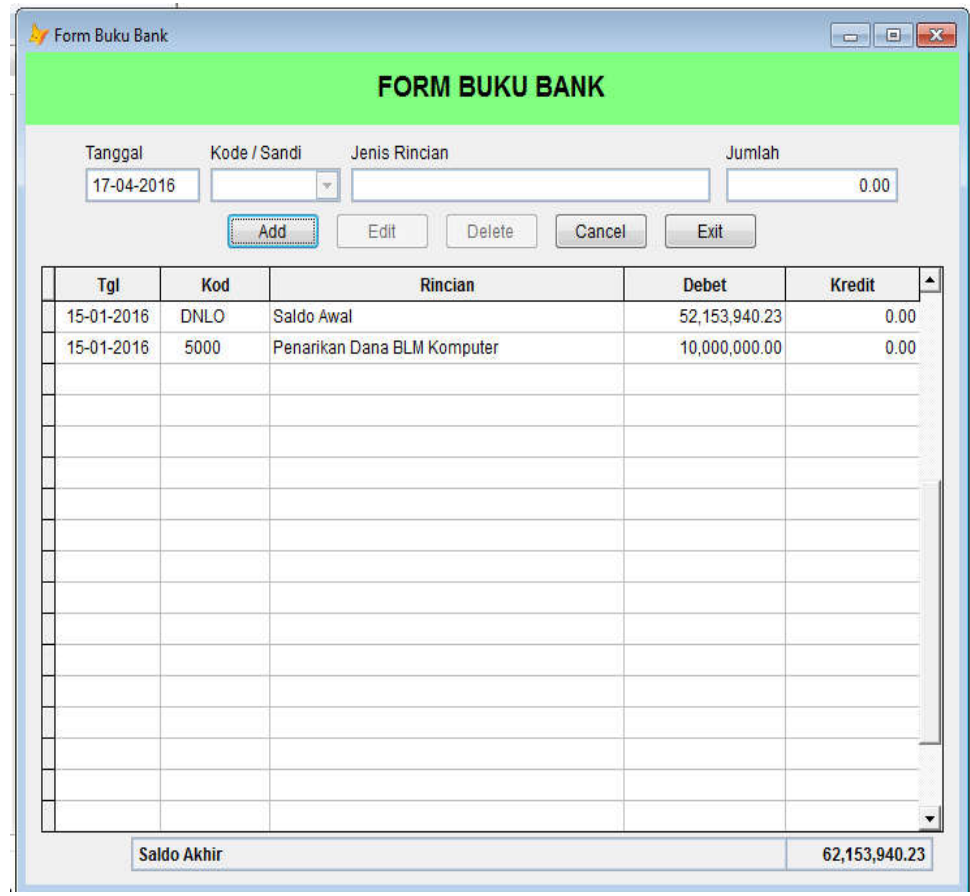

Gambar 10. Tampilan Form Transaksi Buku Bank

Sedangkan form buku kas keluar digunakan untuk mencatat setiap detail dari pengeluaran yang dilakukan. Berikut ini tampilan dari form buku kas keluar :

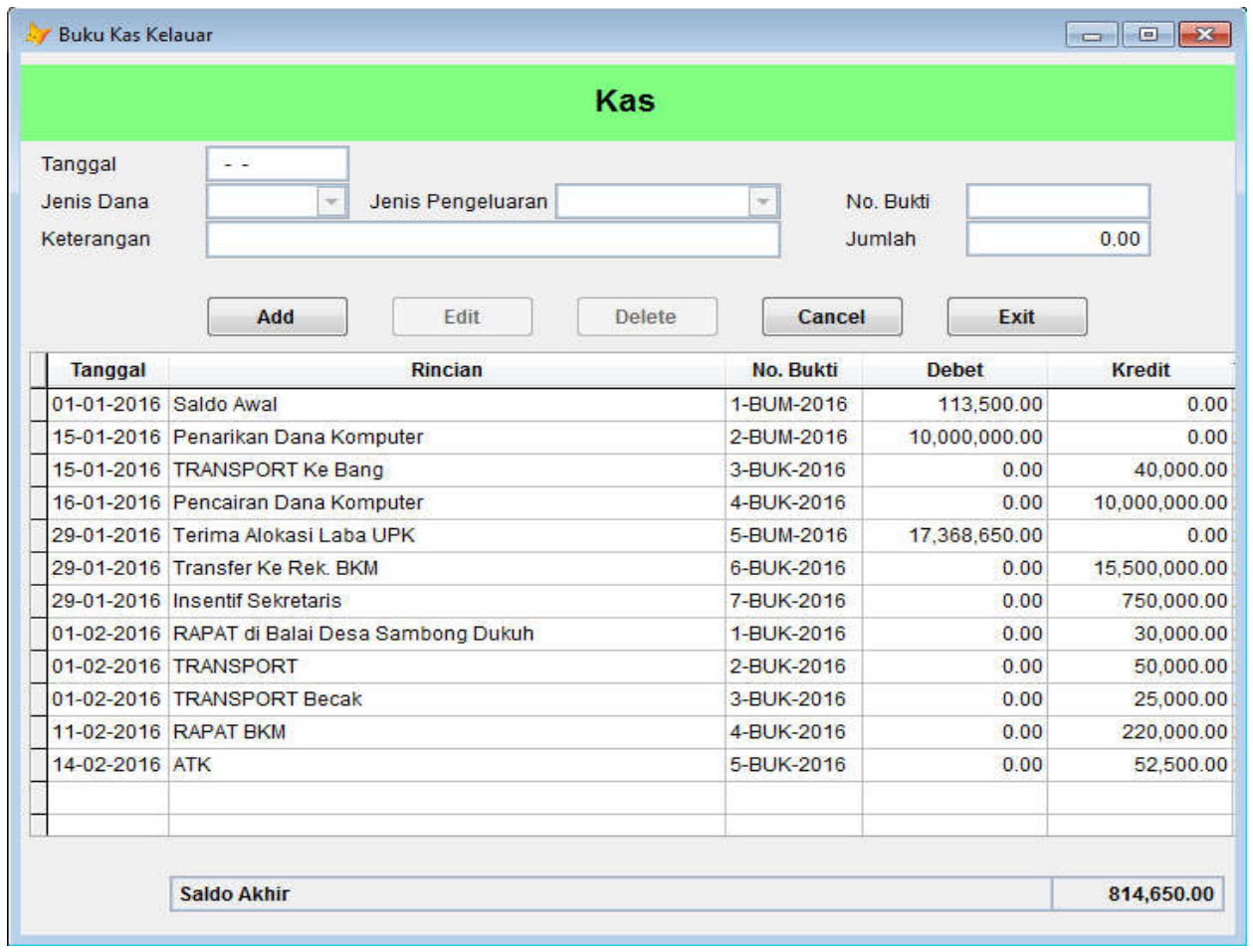

Gambar 11. Tampilan Form Transaksi Buku Kas 


\section{Penutup}

\subsection{Kesimpulan}

Dari berbagai proses dan hasil penelitian, peneliti dapat mengambil kesimpulan:

1. Sistem ini dirancang untuk memudahkan Sekretaris BKM dalam hal Pencatatan Dana, pengolahan Dana serta Pelaporannya.

2. Sistem pengelompokan secara otomatis perbulan. Sehingga Sekretaris hanya memasukkan dan mencatat setiap transaksi yang ada kemudian mencetaknya.

3. Dalam sistem ini hanya mencetak 2 proses, yakni pada proses neraca dan arus kas.

\subsection{Saran}

1. Menambahkan Rencana Anggaran Kegiatan tahun yang akan dating atau disebut RENTApada BKM Tambak Rejo.

2. Menambahkan Prosentasi Hasil Kinerja Pendapatan Belanja Pada BKM Tambak Rejo.

3. informasi ini masih bisa dikembangkan lebih baik lagi, Sistem keamanan databasenya misalnya menggunakan Mysql. Laporan Tiap Alokasi dana (Lingkungan, Sosial, Pelatihan, dan BOP.). Penambahan Prosentase dana yang digunakan.

\section{DAFTAR PUSTAKA}

Abdulloh, Rohi. 2015. Web Programming is Easy. Jakarta: PT. Elex Media Komputindo

Anonim. 2014. Petunjuk Teknis Pendampingan, Pencairan Dan Pemanfaatan Dana Bantuan Langsung Masyarakat (BlM). Jombang: Direktorat Jenderal Cipta Karya - Kementerian Pekerjaan Umum.

Cempaka Wangi, Annisa Meta. dan Prasetiono. Analisis Manajemen Laba Dan Kinerja Keuangan Perusahaan Pengakuisisi Sebelum Dan Sesudah Merger Dan Akuisisi Yang Terdaftar Di Bursa Efek Indonesia Tahun 2008-2009. Skripsi. Semarang : Fakultas Ekonomi Universitas Diponegoro

Fakultas Teknologi Informasi Universitas K.H. A. Wahab Hasbulloh. 2015. Buku Pedoman Penulisan Skripsi S-1 Fak. Teknologi Informasi Unwaha. Jombang: Fakultas Teknologi Informasi, Universitas K.H. A. Wahab Hasbulloh.

Karyono, Hery. 2007. Microsoft Visual FoxPro 9.0 Mengolah Data Melalui Jendela Commanddan Menu Utama. Jakarta: PT. Elex Media Komputindo.

Kurnia Wijayanti, Sjamsiar Sjamsudin, Mochamad Rozikin, Upaya Badan Keswadayaan Masyarakat (Bkm) Dalam Pemberdayaan Masyarakat (Studi Di Kantor Kelurahan Tanjungrejo, Kecamatan Sukun, Kota Malang), Jurnal Administrasi Publik (JAP), Vol. 1, No. 10, Hal. 35-40

Sujono. 2013. Sistem Pendaftaran Mahasiswa Baru Secara Online Dengan Menggunakan Bahasa Pemrograman PHP pada STMIK Bahrul Ulum jombang. Skripsi. Jombang: Prodi Sistem Informasi, Sekolah Tinggi Manajemen Informatika dan Komputer Bahrul Ulum jombang. 